Creative Commons User License: CC BY-NC-ND

Abstracted by: EBSCOhost, Electronic Journals Service (EJS),

Google Scholar, Journal Seek, Scientific Commons,

Food and Agricultural Organization (FAO), CABI and Scopus
Journal of Agricultural Extension

Vol. 23 (3) July, 2019

ISSN(e): 24086851; ISSN(Print); 1119944X

http://journal.aesonnigeria.org

http://www.ajol.info/index.php/iae

Email: editorinchief@aesonnigeria.org

\title{
Value Addition on Cassava Wastes among Processors in Oyo State, Nigeria
}

https://dx.doi.org/10.4314/jae.v23i3.12.

\section{Oyewole, Mojisola Fauziyah,}

Department of Agricultural Extension and Rural Development, University of Ibadan, Nigeria

oyemojidola2@yahoo.com; 08023250459

Eforuoku, Favour,

Department of Agricultural Extension and Rural Development, University of Ibadan, Nigeria

favouriteeforuoku@gmail.com, 08065193845, Corresponding Author

Abstract

This study assessed the strategies used in cassava wastes value addition among cassava processors in Oyo State. Multistage sampling procedure was used to draw 110 cassava processors as respondents. Questionnaire was used to collect information from respondents, while data were analysed using descriptive statistics and Pearson Product Moment Correlation. Over half (57.3\%) of the respondents had between 1 and 10 years of processing experience. Respondents had high knowledge on sun drying $(\bar{x}=0.75)$ and compost making $(\bar{x}=0.62)$ as cassava waste value addition strategies. Source of increased income $(\bar{x}=0.97)$ was perceived to be a major benefit of value addition. High moisture content of cassava wastes $(\bar{x}=1.64)$ and inadequate information on cassava waste utilisation processes $(\bar{x}=1.61)$ were constraints to value addition practices. Sun drying $(\bar{x}=1.87)$ and composting $(\bar{x}=1.68)$ were the most utilised value addition strategies used. Significantly related to utilisation of cassava waste value addition were knowledge on biogas ( $r=0.25)$, composting $(r=0.10)$, fermentation ( $r=0.55)$ and ethanol $(r=0.19)$. Extension agent and government should sensitize and train cassava processors on cassava waste value addition.

Keywords: Cassava waste, Cassava processors, Value Addition 
Creative Commons User License: CC BY-NC-ND

Abstracted by: EBSCOhost, Electronic Journals Service (EJS),

Google Scholar, Journal Seek, Scientific Commons,

Food and Agricultural Organization (FAO), CABI and Scopus
Journal of Agricultural Extension

Vol. 23 (3) July, 2019

ISSN(e): 24086851; ISSN(Print); 1119944X

http://journal.aesonnigeria.org

http://www.ajol.info/index.php/jae

Email: editorinchief@aesonnigeria.org

\section{Introduction}

Cassava is the third most important source of calories in the tropics, after rice and maize (Food Safety Network, 2014). Millions of people depend on cassava for food security and income generation (Legg et al., 2014). Although this crop is considered as a staple in many countries, this situation has changed in some countries where cassava is now an industrial and cash crop (Reincke, Vilvert, Fasse, Graef, Sieber, and Lana, 2018) In Nigeria, cassava remains a staple food of choice across cultures and social divides (Food and Agriculture Organisation-FAO, 2014). It contributes significantly to the livelihood of farmers, processors and traders (Fonji, Temegne and Ngom, 2017). An array of food products such as starch, garri, cassava flour, and fufu are commonly processed from cassava tubers hence there has been a steady rise in production and cultivation of cassava in Nigeria, from 32,010,000 tons in 2000 to $57,134,478$ tons in 2016 (FAO, 2016; FAO, 2014). Nigeria now ranks as the highest cassava producing country in the world. Other countries are: Thailand (31 million MT.), Brazil (21 million MT.), Indonesia (21 million MT.) and Ghana (18 million MT.) (FAO, 2016).

Increase in production invariably implies an increase in the level of waste generated from the processing of cassava tubers into other products. During the processing of cassava tubers into these essential products, an enormous quantity of waste is produced in form of solid waste ch peelings and pulp sieviates, liquid waste and gaseous emission consisting of moisture and cyanide (Ohimain, Silas-Olu, and Zipamoh, 2013). These wastes contain highly polluting bio-materials which can affect the environment in different ways. For example, waters from cassava processing is particularly toxic and makes surface waters poisonous, while improper disposal of cassava peels and effluents pose serious threat to the environment and human health (Olukanni and Olatunji, 2018). These wastes (peels, waste water and other solid constituents) are often not properly disposed and usually constitute nuisance to the environment. Residents close to the site where the waste is indiscriminately dumped suffer from problems of unbearable odour, presence of poisonous gases and a general unhealthy environment. The result is discomfort, anxiety, mosquito infestation and frequent illness (Obueh and Odesiri-Eruteyan, 2016). Therefore, there is 
Creative Commons User License: CC BY-NC-ND

Abstracted by: EBSCOhost, Electronic Journals Service (EJS),

Google Scholar, Journal Seek, Scientific Commons,

Food and Agricultural Organization (FAO), CABI and Scopus
Journal of Agricultural Extension

Vol. 23 (3) July, 2019

ISSN(e): 24086851; ISSN(Print); 1119944X

http://journal.aesonnigeria.org

http://www.ajol.info/index.php/iae

Email: editorinchief@aesonnigeria.org

need for value addition to transform cassava waste into less environmental harmful products that are beneficial.

Value addition is the transformation of raw materials into forms of products with higher value and diversified utilities (Popoola, Adebayo, Sodiya, and Adebowale, and Adeoye, 2015). Hence, it offers the possibility of creating marketable products from waste. Cassava waste is enormous, it can be processed and converted into useful products such as methane (biogas), ethanol, surfactant, fertilizer and even feed for livestock. Specifically, cassava peel can be utilized as a medium for mushroom cultivation or can be used to produce compost (Kortei, Dzogbefia, and Obodai, 2014); Odediran and Ojebiyi, 2017). In Vietnam, solid waste from cassava (mainly pulp) is sun dried and used as fuel for production of maltose (Gustafson, 2015). Already more than $80 \%$ of the cassava solid waste is being used productively, primarily as pig and fish feed and also for other innovative purposes in many counties (Lukuyu, 2014). However, in Nigeria where cultivation and processing of cassava tubers is a common livelihood activity only an insignificant proportion is converted to useful products as a large portion are usually thrown along the roadsides. The peels and other wastes such as chaffs are being considered as an "inconvenience" rather than a potential resource (Odediran, Ashimolowo, Sodiya, Sanni, Adebayo, Ojebiyi, and et al., 2015).

The study therefore assessed strategies of cassava wastes value addition among cassava processors in Oyo State, Nigeria. The utilisation of cassava wastes has the potential to increase rural farm income through livelihood diversification as well as reduce environmental pollution caused by waste disposal. Specifically, the study highlights the knowledge of cassava processor on various cassava wastes value addition, perceived benefits of cassava wastes value addition, constraints to cassava wastes value addition and relationship between knowledge on cassava wastes value addition and extent of utilisation.

\section{Methodology}

The study was carried out in Oyo State, Nigeria $\left(8.1196^{\circ} \mathrm{N}, 3.4196^{\circ} \mathrm{E}\right)$ and the population of the study included all cassava processors in the State. Multistage sampling procedure 
Creative Commons User License: CC BY-NC-ND

Abstracted by: EBSCOhost, Electronic Journals Service (EJS),

Google Scholar, Journal Seek, Scientific Commons,

Food and Agricultural Organization (FAO), CABI and Scopus
Journal of Agricultural Extension

Vol. 23 (3) July, 2019

ISSN(e): 24086851; ISSN(Print); 1119944X

http://journal.aesonnigeria.org

http://www.ajol.info/index.php/jae

Email: editorinchief@aesonnigeria.org

was used to select respondents for the study. The first stage involved the purposive selection of Oyo west, Oyo east and Atiba Local Government Areas (LGAs) from the 33 local government areas in Oyo State due to large number of processors in these LGAs. The second stage involved the use of simple random sampling procedure to select $10 \%$ of cassava processors (1140) from the list of registered cassava processors in the three LGAs. This list was collected from the Agricultural Development Programme (ADP) services. A total of 114 processors were sampled. However, four questionnaires were discarded because they were incomplete. Leaving a total of 110 for analysis. Data were analysed using frequency, percentage, and mean, as descriptive statistics, while Chi square and Pearson's Product Moment Correlation (PPMC) were used as inferential statistics.

\section{Results and Discussion}

\section{Characteristics of Cassava Processing}

Result on Table 1 reveals that $57.3 \%$ of the respondents had been in cassava processing for between 1-10 years, $46.4 \%$ of respondents processed cassava at least once a week and the majority $(77.3 \%)$ processed cassava basically for commercial purpose. This suggests that large cassava wastes are generated by respondents. According to Olukanni and Olatunji (2018), huge amount of wastes is generated from cassava processing.

Table 1: Characteristics of cassava processors

\begin{tabular}{lll}
\hline Variables & Category & Percentage \\
\hline Processing & $1-10$ & 57.3 \\
experience(years) & $11-20$ & 24.5 \\
& $21-30$ & 14.5 \\
& $31-40$ & 3.6 \\
Processing & Daily & 30.9 \\
frequency & & \\
& Weekly & 46.4 \\
Purpose of & Fortnightly & 22.7 \\
processing & Domestic & 24.7 \\
\hline
\end{tabular}

Source: Field Survey, 2017 
Creative Commons User License: CC BY-NC-ND

Abstracted by: EBSCOhost, Electronic Journals Service (EJS),

Google Scholar, Journal Seek, Scientific Commons,

Food and Agricultural Organization (FAO), CABI and Scopus
Journal of Agricultural Extension

Vol. 23 (3) July, 2019

ISSN(e): 24086851; ISSN(Print); 1119944X

http://journal.aesonnigeria.org

http://www.ajol.info/index.php/iae

Email: editorinchief@aesonnigeria.org

\section{Knowledge of Processors on Cassava Waste Value Addition}

Results in Table 2 reveal the knowledge of respondents on various value addition obtainable from cassava waste. Such as; sun drying, fermentation, composting, biogas and ethanol making. Results reveal that there was high knowledge on sun drying peels being helpful in reducing hydro-cyanide content in the cassava peels $(\bar{x}=0.84)$, drying cassava peels at a high temperature $(\bar{x}=0.88)$, sun drying of cassava peels prevents diseases when animals consume peels as food $(\bar{x}=0.85)$ and compost from cassava wastes can be done in less than one month $(\bar{x}=0.77)$. However, respondents had low knowledge on statements that yeast can be obtained from fermenting mesh $(\bar{x}=0.21)$, heat is required for the process of ethanol production from cassava wastes $(\bar{x}=0.36)$ and that it was more economical to produce ethanol from cassava waste than from cassava $(\bar{x}=0.26)$. Overall, respondents had good knowledge on sun drying as method of value addition with a mean value of 0.75 . This was followed by knowledge on composting making and fermentation with mean values of 0.62 and 0.32 respectively. This implies that respondents had good knowledge of the value addition of certain strategies such as sun drying and composting, while there was low knowledge on use of cassava waste for biogas, fermentation of waste and ethanol. This corroborates the findings of Odediran et al (2015) that aside sun-drying of peels for feeding animals, majority of cassava processors were not aware of others forms of cassava peel utilisation and explains why cassava peels were being disposed as waste by the majority of the cassava processors. 
Table 2: Knowledge of processors on cassava wastes value addition

\begin{tabular}{|c|c|c|}
\hline Knowledge statement & Mean $(\bar{x})$ & Rank \\
\hline \multicolumn{3}{|l|}{ Knowledge on sun drying } \\
\hline $\begin{array}{l}\text { Sun drying cassava peels helps to reduce hydro cyanide content } \\
\text { in the cassava peels }\end{array}$ & 0.84 & 3 \\
\hline Drying cassava peels at a high temperature is good & 0.88 & 1 \\
\hline Concrete floor is not good for drying cassava peels & 0.41 & 4 \\
\hline $\begin{array}{l}\text { Sun drying prevents diseases in animal fed with sun dried } \\
\text { cassava peels }\end{array}$ & 0.85 & 2 \\
\hline $\begin{array}{l}\text { Overall mean for sun drying } \\
\text { Knowledge on composting }\end{array}$ & 0.75 & \\
\hline It is better to sundry cassava peels slowly & 0.56 & 5 \\
\hline When cassava are heaped up, it can decompose & 0.87 & 1 \\
\hline Water retards the decomposition process of cassava peels & 0.54 & 6 \\
\hline Compost from cassava peel is good source of fertilizer & 0.65 & 3 \\
\hline Plant grown by compost are more durable and expensive & 0.59 & 4 \\
\hline Compost from cassava can be done in less than one month & 0.77 & 2 \\
\hline Plant grown on compost are poisonous & 0.39 & 7 \\
\hline $\begin{array}{l}\text { Overall mean for composting } \\
\text { Knowledge on cassava fermentation }\end{array}$ & 0.62 & $2^{\text {nd }}$ \\
\hline It is necessary to sundry before fermentation & 0.41 & 1 \\
\hline $\begin{array}{l}\text { Fermentation process will take about two hours } \\
\text { Yeast can be obtained from fermenting mesh in effluent from }\end{array}$ & 0.35 & $\begin{array}{l}2 \\
3\end{array}$ \\
\hline cassava processing sites & 0.21 & \\
\hline $\begin{array}{l}\text { Overall mean for fermentation } \\
\text { Knowledge on biogas production }\end{array}$ & 0.32 & $3^{\text {rd }}$ \\
\hline $\begin{array}{l}\text { Cassava wastes should be cut into small pieces before loading } \\
\text { into the machine }\end{array}$ & 0.28 & 1 \\
\hline it is necessary to sundry peels before loading in the machine & 0.28 & 1 \\
\hline $\begin{array}{l}\text { Overall mean for biogas production } \\
\text { Knowledge on ethanol }\end{array}$ & 0.28 & $4^{\text {th }}$ \\
\hline $\begin{array}{l}\text { Ethanol from cassava wastes is more economical to produce } \\
\text { than ethanol from cassava }\end{array}$ & 0.33 & 1 \\
\hline Heat is required for the process of ethanol from cassava wastes & 0.23 & 2 \\
\hline Overall mean for ethanol production & 0.28 & $4^{\text {th }}$ \\
\hline
\end{tabular}

Source: Field Survey, 2017 
Creative Commons User License: CC BY-NC-ND

Abstracted by: EBSCOhost, Electronic Journals Service (EJS),

Google Scholar, Journal Seek, Scientific Commons,

Food and Agricultural Organization (FAO), CABI and Scopus

http://eoi.citefactor.org/10.11226/v23i3
Journal of Agricultural Extension

Vol. 23 (3) July, 2019

ISSN(e): 24086851; ISSN(Print); 1119944X

http://journal.aesonnigeria.org

http://www.ajol.info/index.php/jae

Email: editorinchief@aesonnigeria.org

\section{Perceived Benefits of Cassava Wastes Value Addition}

Table 3 presents the benefits that processors derive from cassava wastes value addition. It reveals that the benefits from cassava waste value addition were increased in income $(\bar{x}$ $=0.97)$, reduction in expenses on animal feed $(\bar{x}=0.92)$, improvement in the quality of animal feed $(\bar{x}=0.90)$, improve means of livelihood $(\bar{x}=0.88)$ and prevention of disease spread within the community $(\bar{x}=0.77)$. This implies that utilisation of cassava waste has immense benefit to the cassava processor. Siddhartha, Nitscke, and Contiero (2012), posited that cassava wastes can serve as substrate for microbial processes in the production of different products that are beneficial. Although cassava tubers has become an integral part of commercial animal feed production (Omede, Ahiwe, Zhu, Fru-Nji, and lji, 2018), smallholder farmers in the rural areas find cassava peels as a cheap source of feed for livestock production (Ekop, Simonyan, and Evwierhoma, 2019).

\section{Table 3: Perceived benefits of cassava wastes value addition}

\begin{tabular}{ll}
\hline Items & Mean $(\bar{x})$ \\
\hline Increased income & 0.97 \\
Reduction in expenses on animal feed & 0.92 \\
Improvement in the quality of animal feed & 0.90 \\
Improve means of livelihood & 0.88 \\
Prevention of disease spread within the community & 0.77 \\
Effective method of environmental wastes management & 0.73 \\
Provide fertilizer for crops & 0.64 \\
\hline
\end{tabular}

Source: Field Survey, 2017

\section{Constraints to Cassava Wastes Value Addition}

Table 4 shows the constraints to cassava wastes value addition. It reveals that high moisture content of cassava wastes $(\bar{x}=1.64)$ was the most severe constraints. This could be linked to the facilitating effects of moisture in decay. This was followed by inadequate 
Creative Commons User License: CC BY-NC-ND

Abstracted by: EBSCOhost, Electronic Journals Service (EJS),

Google Scholar, Journal Seek, Scientific Commons,

Food and Agricultural Organization (FAO), CABI and Scopus
Journal of Agricultural Extension

Vol. 23 (3) July, 2019

ISSN(e): 24086851; ISSN(Print); 1119944X

http://journal.aesonnigeria.org

http://www.ajol.info/index.php/iae

Email: editorinchief@aesonnigeria.org

information on cassava waste utilisation processes $(\bar{x}=1.61)$. Also, inaccessibility of processing materials such as biogas limits the use of cassava waste value addition processes. This finding corroborates Diarra, and Devi (2015) that fresh cassava peels can spoil rapidly on account of the high moisture and was a major factor limiting the use of cassava waste for other products, while Addulsalam-Saghir and Adeuyi (2018) noted that inadequate access to information, and low market opportunity were constraints faced in the utilisation of cassava peels.

Table 4: Constraints to use of cassava wastes value addition strategies

\begin{tabular}{lll}
\hline Constraints & Mean $(\bar{x})$ & Rank \\
\hline High moisture content of cassava waste & 1.64 & 1 \\
Inadequate information on cassava waste utilisation processes & 1.61 & 2 \\
Seasonal/inadequate sunshine for sun-drying of cassava waste & 1.51 & 3 \\
Low market demand for cassava waste value added products & 1.50 & 4 \\
Lack of space for adequate processing e.g. sun drying & 1.45 & 5 \\
Inadequate capital to start cassava waste value addition & 1.41 & 6 \\
High cost of some materials for value addition e.g. biogas & 1.29 & 7 \\
Long value addition process & 1.12 & 8 \\
\hline
\end{tabular}

Source: Field Survey, 2017

\section{Strategies Used for Cassava Wastes Value Addition}

Table 5 shows that the majority, frequently (90.0\%) used sun drying as value addition strategy, while composting was occasionally practiced (59.1\%). Other strategies such as biogas making (81.8\%), fermentation (81.8\%) and ethanol making (90.9\%) were never practiced by the majority of the respondents. Table 10 reveals that overall, the level of cassava wastes utilisation was low (90.9\%) among the majority. In the opinion of Odediran and Ojebiyi (2017), the low utilisation of cassava wastes value addition technology could be as a result of lack of awareness of the strategies by the cassava processors. This implies that much still need to be done to make cassava processors utilize the strategies. 
Creative Commons User License: CC BY-NC-ND

Abstracted by: EBSCOhost, Electronic Journals Service (EJS),

Google Scholar, Journal Seek, Scientific Commons,

Food and Agricultural Organization (FAO), CABI and Scopus

http://eoi.citefactor.org/10.11226/v23i3
Journal of Agricultural Extension

Vol. 23 (3) July, 2019

ISSN(e): 24086851; ISSN(Print); 1119944X

http://journal.aesonnigeria.org

http://www.ajol.info/index.php/jae

Email: editorinchief@aesonnigeria.org

Table 5: Strategies used for cassava wastes value addition

\begin{tabular}{ll}
\hline Strategy & Mean $(\bar{x})$ \\
\hline Sun drying & 1.87 \\
Composting & 0.68 \\
Biogas production & 0.18 \\
Fermentation & 0.18 \\
Ethanol making & 0.09 \\
\hline
\end{tabular}

Source: Field Survey, 2017

\section{Relationship between Knowledge and Utilisation of Cassava Wastes Value Addition}

The results in Table 6 reveal that there was a significant relationship between perceived knowledge on biogas production $(r=0.26)$, composting $(r=0.11)$, fermentation $(r=0.55)$ ethanol making, and the utilisation of cassava wastes value addition strategies $(r=0.19)$. This implies that with more knowledge on biogas, alcohol, compost production, and fermentation as cassava wastes value addition strategies, there will be higher the utilisation of cassava wastes. According to Popoola, Adebayo, Sodiya, Adebowale and Adeoye, (2015), increased awareness and knowledge of various cassava peels value addition strategies will lead to higher utilisation of value addition strategy. Also, the result revealed that there was no significant relationship between knowledge on sun drying and utilisation of cassava wastes value addition strategies $(r=0.14)$. This implies that knowledge on sun drying has doesn't translate to its utilisation as a strategy of cassava wastes value addition. Some processors do not bother to sun dry and prefer to dispose the cassava waste due to the high moisture content of the waste and stress involved in sun drying (Zhang, Xie, Xin, Khanal, and Zhou, 2016). 
Creative Commons User License: CC BY-NC-ND

Abstracted by: EBSCOhost, Electronic Journals Service (EJS),

Google Scholar, Journal Seek, Scientific Commons,

Food and Agricultural Organization (FAO), CABI and Scopus
Journal of Agricultural Extension

Vol. 23 (3) July, 2019

ISSN(e): 24086851; ISSN(Print); 1119944X

http://journal.aesonnigeria.org

http://www.ajol.info/index.php/jae

Email: editorinchief@aesonnigeria.org

Table 6: Relationship between knowledge and utilisation of cassava wastes value addition

\begin{tabular}{ll}
\hline Variable (knowledge) & r-value \\
\hline Sun drying & 0.14 \\
Composting & $0.26^{\star}$ \\
Biogas production & $0.11^{\star}$ \\
Fermentation & $0.55^{\star}$ \\
Ethanol making & $0.19^{\star}$
\end{tabular}

${ }^{*} \mathrm{P} \leq 0.05$

\section{Conclusion and Recommendation}

Utilisation of cassava waste value addition strategies was low. Processors were constrained by high moisture content of cassava wastes and inadequate information on value addition processes. Also, knowledge on cassava wastes value addition strategies was low. This is in spite of the high perceived benefit of using cassava wastes value addition. There is a need for extension agent, government and non-governmental organizations to sensitize and train cassava processors on various utilisation of cassava waste value addition strategies. Also, research should be geared towards finding cheaper and easier ways of value addition in rural communities where cassava production and processing are high.

\section{References}

Addulsalam-Saghir, P. and Adeuyi O. O. (2018). Cassava peel utilisation among rural households of Southwest, Nigeria. Food chain, 7(2), 87-99.

Diarra, S. S. and Devi, A. (2015). Feeding value of some cassava by-products meal for poultry: A review. Pakistan Journal of Nutrition, 14 (10), 735-741.

Ekop I.E., Simonyan K.J., and Evwierhoma, E. T. (2019). Utilization of cassava wastes for value added products: An overview. International Journal of Scientific Engineering and Science. 3 (1), 31-39.

Food and Agriculture Organization- FAO (2016). FAOSTAT. Food and Agriculture Organization of the United Nations, Statistics Division. 
Food and Agriculture Organization- FAO (2014). FAOSTAT. Food and Agriculture Organization of the United Nations, Statistics Division.

Fonji, F. T., Temegne, C. N. and Ngom, F. A. (2017). Quantitative analysis of cassava products and their impacts on the livelihood of value chain actors: Case of the centre region of Cameroon. Annual Research \& Review in Biology, 15(6), 1-14.

Food Safety Network. (2014). Cassava Nutritional Network. FSNET: University of Guelph, March 14.

Gustafson, A. Y. (2015) Wastewater to renewable energy at a tapioca factory in Vietnam In-situ evaluation of anaerobic covered pond treating high strength industrial wastewater. A Master's thesis, Water and Environmental Engineering in the Department of Chemical Engineering, LUND University.

Kortei, N. K., Dzogbefia, V. P. and Obodai, M. (2014). Assessing the effect of composting cassava peel based substrates on the yield, nutritional quality, and physical characteristics of Pleurotus ostreatus (Jacq. ex Fr.) Kummer. Biotechnology Research International. 57(1), 1-9.

Legg, J.P., Somado, E.A., Barker, I., Beach, L., Ceballos, H., Cuellar, W. and et al. (2014). A global alliance declaring war on cassava viruses in Africa. Food Security, 6(1), 231-248.

Lukuyu, B., Okike, I., Duncan, A., Beveridge, M. and Blümmel, M. (2014). Use of cassava in livestock and aquaculture feeding programs. ILRI Discussion Paper 25. Nairobi, Kenya: International Livestock Research Institute

Obueh, H. O. and Odesiri-Eruteyan, E. (2016). A study on the effects of cassava processing wastes on the soil environment of a local cassava mill. Journal of Pollution Effects \& Control, 4(4), 1-4.

Odediran, O. F. and Ojebiyi, W. G. (2017). Cassava processors' willingness to utilise cassava peel for mushroom production in Southwest, Nigeria. International Journal of Agricultural Policy and Research, 5(4), 86-93.

Odediran, O. F., Ashimolowo, O. R., Sodiya, C. I., Sanni, L. O., Adebayo, K., Ojebiyi, W. G. and et al. (2015). Utilisation forms among cassava processors in rural communities of Southwest, Nigeria. International Journal of Applied Agricultural and Apicultural Research, 11(1\&2), 93-102,

Ohimain, E. I., Silas-Olu, D. I and Zipamoh, Y. T (2013). Biowastes generation by small scale cassava processing centres in Wilberforce Island, Bayelsa State, Nigeria. Greener Journal of Environmental Management and Public Safety. 2 (1), pp. 5159. 
Creative Commons User License: CC BY-NC-ND

Abstracted by: EBSCOhost, Electronic Journals Service (EJS), Google Scholar, Journal Seek, Scientific Commons,

Food and Agricultural Organization (FAO), CABI and Scopus
Journal of Agricultural Extension

Vol. 23 (3) July, 2019

ISSN(e): 24086851; ISSN(Print); 1119944X

http://journal.aesonnigeria.org

http://www.ajol.info/index.php/jae

Email: editorinchief@aesonnigeria.org

Omede, A. A., Ahiwe, E. U., Zhu, Z. Y., Fru-Nji, F. and lji, P. A. (2018). Improving Cassava Quality for Poultry Feeding Through Application of Biotechnology. Cassava. Published by INTECH Pp. 240-263

Onyemauwa, C. S. (2012). Analysis of women participation in cassava production and processing in Imo State, Southeast, Nigeria. Agricultura Tropica Et Subtropica, 45(2), $72-77$.

Popoola, T. O., Adebayo, K., Sodiya, C. I., Adebowale, A. A. and Adeoye, A.S. (2015). Utilisation of cassava peels value addition strategies by cassava processors in southwest Nigeria. Journal of Sustainable Development, 12(1), 44-51.

Reincke, K., Vilvert, E., Fasse, A., Graef, F., Sieber, S. and Lana, M. A. (2018). Key factors influencing food security of smallholder farmers in Tanzania and the role of cassava as a strategic crop. Food Security, 10, (4), 911-924.

Siddhartha G.V.A.O. Nitscke, C. M., and Contiero, J. (2012). Biotechnological Potential of Cassava Residues: Peel, Bagasse and Wastewater. In Colleen M. Pace. (Eds) Agriculture Issues and Policies: Cassava Farming, Uses and Economic Impact (pp, 79-98). NOVA Science publishers Inc. New York.

Zhang, M., Xie, L., Xin, Z., Khanal, S. K., and Zhou, Q. (2016). Biorefinery approach for cassava-based industrial wastes: current status and opportunities. Bioresource technology, 21(5), 50-62. 